\title{
pH is a Neurally Regulated Physiological System. Increased Acidity Alters Protein Conformation and Cell Morphology and is a Significant Factor in the Onset of Diabetes and Other Common Pathologies
}

\author{
Graham Wilfred Ewing*
}

Montague Healthcare, Mulberry House, 6 Vine Farm Close, Cotgrave, Nottingham NG12 3TU, UK

\begin{abstract}
Background: The body's physiological stability is maintained by the influence of the autonomic nervous system and the dynamic interaction of the organ systems which regulate all aspects of the body's function. These physiological systems and their function have been overlooked by the genetic paradigm. A better understanding of these systems may lead to an improved understanding of the fundamental relationship involving sense perception, neural function and organ networks, and cellular and molecular biology. This article follows earlier articles by the author which illustrate that sleep, blood pressure and blood glucose are neurally regulated physiological systems.
\end{abstract}

Aims: The purpose of this article is to discuss how Grakov's mathematical model of the physiological systems (i) influences the contemporary understanding of the processes which regulate the $\mathrm{pH}$ in biological systems i.e. that $\mathrm{pH}$ is a neurally regulated physiological system; (ii) is a significant factor in the emergence of changes to cell morphology and, ultimately, the onset of pathologies; and (iii) involves environmental factors more commonly associated with phenotype.

Results: It considers the fundamental role played by $\mathrm{pH}$ e.g. regulating the levels and redox state of minerals, protein conformation, the activation of proteins and enzymes, and how this influences metabolic function. It considers the consequences of increased acidity, in particular from alcoholic beverages and acidified soft drinks, and how this influences the processes which regulate the body's physiological stability.

Conclusions: The article concludes that the body's impaired ability to regulate its acidity, exascerbated by the consumption of highly acidic beverages, is a considerably underestimated factor in the subsequent development and onset of many common pathologies e.g. diabetes, cardiovascular diseases, alzheimer's disease, cancers, etc.

Keywords: Cognitive, neuroregulation, top-down, systems biology, physiological systems.

\section{BACKGROUND}

The laws of chemistry characterise every chemical reaction. The prevailing reaction conditions influence the rate at which each reaction proceeds. In this article we consider whether the significance of $\mathrm{pH}$ has been significantly overlooked in biomedical research.

Changes to the $\mathrm{pH}$ of a biochemical system or reaction often influences the structure of chemical components, their level, and subsequently the rate at which these components react. This determines the redox state of minerals; their ability to complex with DNA; their ability to activate enzymatic reactions; and their ability to be filtered and/or eliminated from the body. Altered $\mathrm{pH}$ influences protein conformation and the ability of proteins to react. It influences the characteristics of epigenetic reactions such as methylation, histone de-acetylation, acetylation, phosphorylation, etc.

The body's homeostasis is maintained by neuroregulation of the various organ networks. These multiple physiological systems, their nature and structure, and the factors which

*Address correspondence to this author at the Montague Healthcare, Mulberry House, 6 Vine Farm Close, Cotgrave, Nottingham, NG12 3TU, UK; Tel: 00-44-115-9890304; Fax: 00-44-115-9899826;

E-mails: graham.ewing@montague-diagnostics.co.uk;

graham.ewing@montaguehealthcare.co.uk influence their function, have been recognised but remain poorly defined. Perhaps the greatest insight into these factors is provided by sports physiologists $[1,2]$ who consider the mechanisms which the body employs to enhance its physical performance. These are at variance with the pharmacological disciplines which are geared towards ameliorating the symptoms associated with morbidity and mortality.

The conventional understanding adopted by biomedical research is that the brain's function is essentially independent of the way in which the brain reacts to external stimuli. This ignores that a fundamental aspect of the brain's function is to maintain homeostasis and regulate uncontrolled physical activity; and ignores that sensory signals are converted into biochemical responses which, when experienced as stress, lead to alterations of normal physiology, their manifestation as pathologies and the production of metabolites, and which influence brain function. A better understanding of the physiological systems leads to an understanding of the coordinated function of organs in each neural and organ network i.e. there is a fundamental structural relationship involving sense perception, neural networks, organ networks, and cellular and molecular biology. Extremes of cognitive input, which we perceive as stress, influence cellular and molecular biology [3]. 
The neuroregulation of $\mathrm{pH}$ performs a vital homeostatic function however the prevailing definition of physiological systems makes no reference to acid-base regulation. Contemporary biomedical research focuses almost exclusively on the biochemistries linked to normal protein and enzyme metabolism and often ignores the influence of $\mathrm{pH}$. It focuses almost exclusively on the biochemistries considered to be responsible for the regulation of $\mathrm{pH}$ in the brain whilst (i) ignoring that it is the whole function of the brain which regulates all aspects of behaviour and health; (ii) that neural function is influenced by visceral function and feedback; and (iii) that $\mathrm{pH}$ influences the level and characteristics of minerals which facilitate enzymatic reactions.

Neural activity is influenced by sensory input and memory, and can make rapid changes to intercellular and extracellular $\mathrm{pH}$ [5]. Lowered intercellular $\mathrm{pH}$ influences the levels, redox state and bioavailability of minerals e.g. calcium, magnesium, zinc, etc; and subsequently the action of many proteins and enzymes. Lowered extracellular $\mathrm{pH}$ and increased plasma viscosity influences the neural flow of oxygen, blood glucose, the accumulation of metabolic byproducts, and the rate at which glucose is metabolised. In addition, the maintenance of normal levels of $\mathrm{pH}$ is critical for brain function. The brain receives circa $20 \%$ of the body's total oxygen consumption, and circa $25 \%$ of the body's total supply of glucose [6]. Accordingly the prevailing levels of magnesium, zinc and other minerals, which influence the rate at which insulin (and other processes) are metabolised, are essential for the brain's normal function.

The expression of proteins and their level (genotype) is considered to be indicative of the degree of progression of a particular disease state however many diseases are now recognised to be multifactorial $[7,8]$ and, in many cases, multi-systemic $[4,9]$. This places in doubt upon the ability of individual genes or groups of genes, or protein-based biomarkers, to accurately predict the onset or progression of diseases which have complex origins [4]. The levels of proteins expressed; the epigenetic and/or polygenic factors which influence protein expression; protein conformation; the rate at which proteins react with their reactive substrates (phenotype); the level, redox state and bioavailability of minerals; levels of cofactors; the levels and conformation of substrates; and/or the rate at which minerals, substrates and cofactors are absorbed through the visceral membranes into plasma; must all be considered to be factors in the pathological process(es). Modern disease(s) have genetic and environmental origins. Both are significant.

In addition, the levels of proteins expressed and the rate at which these proteins react influences the natural biofluorescent spectra or biophoton emission. This is indicative of the light absorbed as proteins are energised and of the light emitted as proteins decay [10] which influences visual perception. This mechanism provides the data sets for Grakov's mathematical model which links colour perception to cellular and molecular biochemistry. It incorporates an understanding of the nature and structure of the various physiological systems and how such organ networks function in an apparently coherent or synchronised manner [9].
Contemporary medicine accepts that the study of physiological systems is hugely under-researched yet the lack of suitable tools has hitherto prevented any significant research in this subject. The accepted definition of physiological systems - for example in the Merck Manual appears to be contradicted by medical practice: (i) the GP's consultation is largely based upon an assessment of the patient's systemic stability i.e. of temperature, $\mathrm{pH}$, breathing, digestion, elimination, blood pressure, blood volume, blood glucose, blood cell content, sexual function, posture, sleep; (ii) medical research focuses upon the obvious definitions of physiological systems rather than those which have been accepted by contemporary medical practice e.g. which focuses upon breathing, blood glucose, blood pressure, blood cell content, and blood volume rather than a cardiovascular system; (iii) the contemporary definition of physiological systems ignores functions which are essential for the body's function e.g. the regulation of temperature, $\mathrm{pH}$, sexual function, etc.

The regulation of $\mathrm{pH}$ is perhaps the most complex and sophisticated of all physiological systems (Fig. 1). It comprises: brain; pituitary, thyroid and adrenal glands; liver; pancreas; blood and peripheral blood vessels; lungs and bronchii; skin; stomach; duodenum; kidneys; small and large intestines (origin: Grakov IG). Although the function of each of these organs influences the regulation of $\mathrm{pH}$ there is not yet an acceptance that these organs function as part of a coherent and regulated system.

That molecular biology is influenced by $\mathrm{pH}$ is a fundamental aspect of the study of the body's physiology however it is more difficult to explain how localized variations of $\mathrm{pH}$, at the intracellular and intercellular levels and at different parts of the body can be regulated and moreover that regulated cell function is dependent upon precisely maintained $\mathrm{pH}$ in different sub-systems [11,12]. Perhaps this is not surprising when considering that the path of human evolution started as a relatively small group of cells. The cell evolved the ability to handle different environments e.g.

(i) Light activates proteins. It is fundamental to the growth of all vegetation/plant life and the function of plant cells/photosynthesis.

(ii) Environmental $\mathrm{pH}$ including the levels of minerals eg. calcium, magnesium, etc. Life adapted physically, electrochemically and biochemically.

(iii) Temperature e.g. between typically 33-38C (normal 36.8C.) and denaturation of proteins starts to occur at circa 40C.

(iv) Oxygen e.g. typically $21 \%$ but has been significantly higher (and lower) in the distant past.

Initially cells evolved and adapted to different environments e.g. to differing levels of $\mathrm{pH}$, temperature and oxygen. This occured in the intracellular environment by diffusion through cell membranes and then at the intercellular level through the subsequent development of physiological structures e.g. the lungs; the ability to metabolise calcium and magnesium and subsequently the development of skeletal structure(s); the development of capilliary structures which enabled the body to deal with the 


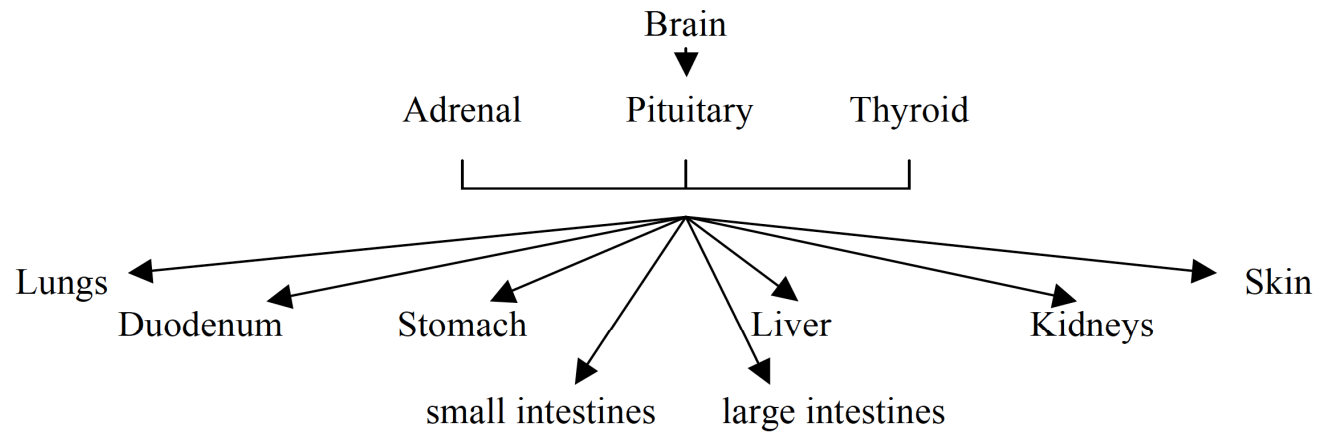

Fig. (1). pH regulation.

absorption and processing of nutrients; and the process of cell division i.e. of reproduction.

The significance of what appears to be minor or insignificant changes to biochemistry are often ignored however there are examples in the human and animal world where apparently minor physiological changes can have profound effects e.g.

- Women taking the contraceptive pill might find that their natural selection of a partner might be adversely influenced [13]

- Clownfish lose their hearing in water which is more acidic than the norm [14] and become attracted to their predators [15].

- $\quad$ The migration of birds and animals, and the mating cycle of ruminants, are triggered by minute changes of light upon the pineal gland.

\section{WHICH ORGANS DOES THE BODY USE TO REGULATE PH?}

The body maintains, at least in the Caucasian, a plasma $\mathrm{pH}$ of 7.364. Homeostatic Limits: if plasma $\mathrm{pH}$ drops below 6.8 or rises above 7.8 , death is likely. The total acid intake has to be balanced by bicarbonate and other buffers e.g. PO4. Imbalance leads to acidosis or, less commonly, alkalosis

The lungs remove excess $\mathrm{CO} 2$, the waste product of glucose metabolism, from the blood. The digestion of food, in particular of proteins, and drink creates acidity to which the pancreas responds by releasing secretin and also by the release of bicarbonate which neutralizes the acidic chyme which enters the duodenum from the stomach. The digestive tract ranges from strongly acidic in the stomach, to slightly acidic (at a pH of typically 5.7-6.7 in the small intestine), $\mathrm{pH}$ $7 /$ neutral in the colon and typically $\mathrm{pH}$ 7-9 in the large intestine. The stomach releases pepsin, other digestive enzymes and hydrochloric acid (maintains the stomach at a $\mathrm{pH}$ of typically 2); thereafter food is churned into chyme by muscular contractions in the stomach. The gallbladder delivers alkaline bile to the duodenum in order to neutralise excess acid and dissolve fatty acids in chyme. The large intestine delivers bicarbonate to maintain the alkaline $\mathrm{pH}$ which is required to sustain the function of over 700 bacteria. The kidneys strive to maintain $\mathrm{pH}$ of urine of typically 6.4. The $\mathrm{pH}$ of the skin is maintained at a $\mathrm{pH}$ of typically $4.5-6.0 . \mathrm{pH} 5.5$ is considered to be the optimum $\mathrm{pH}$ required by the skin [16]. The Extracellular fluid can act as an acid reservoir. Blood plasma (circa 20\%) and interstitial fluid (circa 80\%) make up the extracellular fluid (ECF). This $20 / 80$ balance is balanced by the prevailing osmotic pressure. The bones of the skeletal structures can release calcium and magnesium in order to buffer excess acidity $[17,18]$. This illustrates that the body's regulation of $\mathrm{pH}$ exhibits the characteristics of a physiologically regulated system within defined operating limits.

\section{HOW DOES PH INFLUENCE THE BODY'S PHYSIOLOGY?}

$\mathrm{pH}$ influences the body's physiology in many ways e.g.

3.1. All physical activity whether at rest or in motion creates $\mathrm{CO2}$ which the body must expel in order to sustain its function and physiological stability [19]. The inability to expel $\mathrm{CO} 2$ and to maintain homeostasis progressively destabilises the body's function.

3.2. pH Influences endocrine function and metabolic rate. Lowered $\mathrm{pH}$ influences endocrine function and consequently lowers metabolic rate [20]. It influences the chemical spectrum of hormones emitted [21] which influences metabolic rate [22]. It also reduces the absorption of iodine upon which the thyroid depends.

3.3. $\quad \mathrm{pH}$ is an environmental factor (phenotype) which influences the function of most proteins and enzymes (see Fig. 2). It alters protein conformation and the prevailing levels of minerals which are often essential for protein conformation and reaction e.g. the ability of zinc to complex with insulin. In particular the prevailing level of $\mathrm{pH}$ influences the levels of Sodium and Calcium [23,24], which facilitate the flow of ions across neuronal membranes. This influences the action potentials, rate of neuronal firing and ultimately the fixation of memories. The prevailing $\mathrm{pH}$ influences the absorption and bioavailability of Chromium [25-29] and the balance of iron as FeII/Fe III.

\subsection{The acidity of water and drink}

3.4.1. The quality of drinking water may influence the onset of type 1 diabetes [30] although the mechanisms by which water acidity or mineral content may be involved in the etiology of type 1 diabetes remain unknown. The quality of the water supply, in particular the acidity of drinking water, is implicated in diabetes etiology [30]. 
3.4.2. The intake of acidic and alcoholic drinks alter the natural metabolic processes. Different enzymes (isozymes) metabolise the alcohol at lower $\mathrm{pH}$. This alters lipid metabolism and contributes to weight gain [31].

3.4.3. The incidence of Alzheimer's disease (AD) was higher in localities with relatively high levels of aluminium [32] but was not associated with higher $\mathrm{pH}$ e.g. in drinking water [33] or regular use of antacids [34]. This is significant because many with AD are also diabetic [35].

3.5. The absorption and release of bone calcium buffers the system against increased acidity [36]. Demineralisation of bone is the consequence of significant increases in extracellular acidity [37]. In addition, the influence of acidosis on bone metabolism is more significant in children than adults i.e. when bone structures are growing. Bone metabolism and immunity are interlinked. Immunity is largely a product of bone and spleen metabolism. $\mathrm{pH}$ influences immune function [38,39] and hence influences predisposition to viral and bacterial infections. behavioural) in the case of foetal alcohol syndrome [41-45]. This leads to the degradation of cells and organs, and ultimately leads to the failure of the mechanisms which regulate the function of the kidney, liver and other visceral organs. It requires the production of anti-oxidants to neutralise the damaging effects of such ROS. The completion of this process produces acetic acid which further lowers extracellular $\mathrm{pH}$ before being metabolised in the citric acid cycle to $\mathrm{CO} 2$.

4.2. increased acidity influences the levels and bioavailability of Zinc and other Minerals. Zinc is commonly associated with its role in the metabolism of insulin however it is not solely associated with diabetes. It's ability to complex with proteins prevents islet amyloid polypeptide from agglomerating and forming fibrils e.g. as found in alzheimer's disease, diabetes, and other degenerative diseases. [46]. Acid conditions alter the conformation of insulin thereby enhancing the formation of fibrils [47]; the levels and bioavailability of minerals in particular of zinc [48], magnesium, iron, chromium, etc.

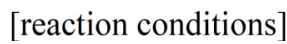

$$
\begin{aligned}
& \text { DNA } \longrightarrow \text { protein } \\
& \text { proteins } \stackrel{[\text { reaction conditions }[\mathrm{H}+]]}{\longrightarrow} \text { uncoiled proteins } \\
& \text { Energy }+ \text { protein }+ \text { substrate } \longrightarrow \text { protein* +metabolites }+ \text { energy }
\end{aligned}
$$

Fig. (2).

\section{HOW DOES THE METABOLISM OF ALCOHOL INFLUENCE THE BODY'S ACIDITY AND ITS FUNCTION?}

4.1. the metabolism of ethyl alcohol creates acidity. A typical human digestive system produces approximately $3 \mathrm{~g}$ of ethanol each day. This arises through the normal digestive and fermentation processes. This degradation of ethanol is therefore an essential feature of the life of most living organisms. It is indicative of the normal levels of alcohol which the body is designed to tolerate. Nevertheless Ethyl Alcohol is a poison which, consumed in excess, can increase susceptibility to morbidity and mortality.

Ethanol is first oxidised to acetaldehyde which forms ROS/free radicals. The enzyme alcohol dehydrogenase is dependent upon the availability of zinc and magnesium [40]. Acetaldehyde is subsequently oxidised to acetic acid which is then converted to Acetyl Co-A and subsequently is broken down in the normal citric acid cycle to $\mathrm{CO} 2$. The rapid conversion of acetaldehyde is essential in order to avoid the damage which reactive oxygen species can have on the body's structure and function e.g. to the kidney and liver in the case of chronic alcoholism, and to birth defects (structural, gene-related,
Lowered levels of zinc suppress the function of carbonic anhydrase and the processes of respiration; digestion, in particular the function of carboxypeptidase which digests proteins; reproductive function, in particular the growth and function of the reproductive organs; signal transduction; metabolism of RNA and DNA, and gene expression; apoptosis; the function of the kidneys and liver; bone metabolism and hence that of immune function; nervous system; etc. It influences the brain, in particular synaptic plasticity, which is implicated in the processes associated with learning. In excess zinc is a neurotoxin and in deficit it slows metabolic function. It is stored in the metallothioneins.

Zinc is mainly bound to albumin and transferrin. This involves a dynamic relationship between iron and zinc i.e. (i) excess iron reduces zinc levels and vice versa; (ii) increased acidity leads to higher levels of iron and lower levels of zinc. In general, the concentration of zinc stays relatively constant irrespective of zinc intake i.e. at normal $\mathrm{pH}$, however this apparent equilibrium is not maintained during changes of $\mathrm{pH}$. Furthermore increased levels of acidity increase the susceptibility of proteins, 
particularly of insulin, to changes of conformation [47], dissociation and potentially of aggregation.

In particular, the growth of cancers may be dependent upon levels of iron which are needed for DNA replication [49] e.g. the occurrence of ferritin is five times greater in women with breast cancer [50].

4.3. Increased acidity influences the conformation of DNA and proteins.

(a) Protein structure is an essential characteristic of the regulatory processes [51,52]. It varies with $\mathrm{pH}$ $[53,54]$ and influences the ability of proteins to react with their substrates.

(b) Genetic modifications, in particular of mutant genes, influence a wide range of medical conditions e.g. proinsulin structure [55], cystic fibrosis [56], cholesterol metabolism, etc.

(c) DNA is coiled around histones. The characteristics of this coiling influences gene function, and hence the expression of proteins, and is associated with learning and memory [57] i.e. the biochemistries which support the recall of memories are unable to perform in the normal manner. Environmental enrichment has been used to enhance gene expression and reestablish the normal biochemistries necessary for the recall of memories and/or function [58].

(d) The conformation of DNA is linked to $\mathrm{pH}[59,60]$.

(e) $\mathrm{pH}$ is invariably linked to the epigenetic factors which alter the fundamental nature and structure of DNA:

- $\quad$ it influences the strength and integrity of DNA e.g. altering/influencing the degree of cross-linking

- $\quad$ it alters the stability/properties of DNA and results in shortened telomeres [61].

- it alters the rate at which proteins react with their reactive substrates.

\section{THE INFLUENCE OF ACIDITY UPON CELL MORPHOLOGY.}

Increased acidity creates changes to protein conformation which influence cell conformation. It may alter cellular structure: (i) proteins change shape and character and consequently their spatial orientation within the cell; (ii) it can alter the spatial arrangement of chromosomes in the cell nucleus [62]; (iii) alter the expression of proteins and (iv) influence the rate of occurrence of chromosomal rearrangements.

The long-term exposure to abnormal levels of $\mathrm{pH}$, in particular to higher levels of acidity, exceed the body's inherent buffering mechanisms and contribute to the early onset of morphological changes which are characteristic of emergent pathologies e.g.

(i) increased blood flow, enlargement of arterial vascular channels, and the development of an inflammatory response; or increased venous outflow (ischaemia)

(ii) cell hyperfunction or hypofunction e.g. in adenal glands. Adrenal hyperfunction is manifest as Cushing's disease and may be stimulated by caffeine, nicotine, etc. Adrenal hypofunction is manifest as Addisons disease.

(iii) abnormal cell growth or apoptosis/cell death [50]. It has been recognised that adjusting tumour $\mathrm{pH}$ has therapeutic potential $[63,64]$

\section{WHICH ENVIRONMENTAL FACTORS INFLUENCE ACID-BASE HOMEOSTASIS?}

Extremes of sensory input influence acid/base homeostasis e.g.

\subsection{Stress}

6.1.1. Stress in its various manifestations suppresses immune function and influences the autonomic nervous system e.g. raising or lowering blood pressure [65]. It lowers immune function and increases the level of susceptibility to viral infections and a range of conditions including type 1 diabetes mellitus [66] and type 2 diabetes mellitus [67]; heart conditions e.g. myocardial infarction, angina pectoris; etc.

Stress can alter the distribution of acidity in the digestive tract $[68,69]$ thereby leading to digestive reflux, duodenal ulcers and/or ulcerative colitis [70]. The influence of stress alters the normal physiological pathways and triggers the onset of pathologies which include the destabilisation of $\mathrm{pH}$ e.g. resulting in asthma [71,72], diabetes mellitus, alzheimer's disease, heart conditions, incontinence, cancers, etc.

In extremes of stress e.g. of fear, the $\mathrm{pH}$ of the amygdala falls and influences the function of the autonomic nervous system thereby stimulating the typical adrenocortical 'flight or fight' response [73]. It is the biochemical consequences of impaired function (e.g. of suffocation which raises levels of $\mathrm{CO} 2$ in the blood and alters brain $\mathrm{pH}$ homeostasis) which we experience as fear, anxiety or panic [74]. The consequences of stress in its many and various manifestations lead to changes to genetic conformation, in particular to our DNA and Chromosomes [75].

6.1.2. Stress influences the genetic pathways. Stress is experienced at different levels. Minor exposures to stress may have a psychological impact, perhaps influencing our future behaviour, but does not significantly influence our physiology. Nevertheless there are examples of DNA methylation which illustrate how absence of fathers in childhood can influence a child's future demeanor [76]. Stress influences the body's physiological stability and ultimately leads to changes of DNA [75]. Recent research has illustrated that stress influences the expression of telomerase $[77,61]$ i.e. the length of DNA shortens with exposure to chronic stress thereby influencing longevity.

The enzyme SIRT-6 is encoded the SIRT-6 gene. The protein SIRT6 is implicated in the mechanisms of DNA repair [78]. The absence of the SIRT6 enzyme influences the degree to which chromatin is compacted. Under normal circumstances SIRT6 regulates the levels of the protein HIF1alpha however the absence of SIRT6 relaxes chromatin conformation, activates glycolytic genes and lowers levels of blood glucose. In addition SIRT6 induced changes to chromatin conformation influences the structure and function of telomeres [79]. SIRT6 requires $\mathrm{NAD}^{+}$as a cofactor. This may be influenced by increased levels of alcohol 
consumption, and associated devitaminisation, and by increased levels of acidity which will influence the stability and levels of $\mathrm{NAD}^{+}$and/or NADH.

\subsection{Light Influences Intercellular pH}

Light acts upon the pituitary gland [80] and subsequently influences the function of other endocrine glands - thyroid, adrenals, etc. It is the medium which transmits cognitive/sensory input. It plays an essential role in the regulation of sleep and hence upon the health of all other physiological systems. Irregular sleep patterns lead to instability in the autonomic nervous system e.g. influencing levels of cortisol, growth hormone, prolactin and vasopressin. Impaired pituitary function can lead to secondary adrenal insufficiency. It influences the function of the HPA-axis leading to primary and secondary adrenal insufficiency e.g. in which the adrenal glands cannot produce sufficient quantities of corticosteroids and hence are unable to properly regulate levels of sodium, potassium and the renal control of absorption/reabsorption of water by the kidneys [81]. This regulation of water is largely controlled by vasopressin which is produced by the hypothalamus but is stored by vesicles within the pituitary gland. In the presence of vasopressin, the kidneys retain water; whilst in the absence of vasopressin the kidneys excrete water. The storage of vasopressin exhibits striking similarities to that of insulin which is complexed in a zinc-based hexamer and may be indicative of a $\mathrm{pH}$-sensitive controlled-release mechanism. In addition, there are indications that light influences the regulation of the intercellular pH-balance $[82,83]$.

\subsection{Diet}

Diet influences gene structure and the subsequent expression of proteins [84].

(a) The high carbohydrate diet has increasingly displaced the traditional vegetable-based diet upon which our predecessors were raised. This contributes to increased acidity, demineralisation and devitamination [85]. A high-fat diet, in particular a diet with high levels of palmitic acid (a significant constituent of cocoa butter used in chocolate manufacture) inactivates the PGC-1 gene by epigenetic modification/ methylation. The PGC-1 gene is involved in carbohydrate and lipid metabolism [86]. The inactivation of the PGC-1 gene leads to the inactivation of other genes and influences the level of proteins expressed [87]. Dietary factors influence the function of genes which are linked to the regulation of blood glucose i.e of diabetes, and hence which influence the expression of proteins such as pro-insulin/insulin. Alterations to $\mathrm{pH}$ influence the metabolism of fat [88].

(b) Caffeine and artificial sweeteners have been linked to increases in acidity [89].

(c) $\mathrm{pH}$ influences the levels and bioavailability of minerals, including Chromium. Significant sources of chromium, which assists the body to regulate blood glucose [90] are to be found in brassicas and cocoa butter.

(d) An alkaline diet influences the elimination of calcium and bone metabolism. Diets which are high in levels of protein and cereals, produce excess acid which increases the rate at which calcium is excreted [91].

(e) The Influence of Acidified Soft drinks and Alcoholic Beverages
Low levels of minerals and in particular zinc and magnesium are the consequences of increased acidity. They are strongly associated with the onset of diabetes and subsequent secondary effects such as cardiovascular disease(s). Low levels of magnesium are linked to muscular spasms and, in the alcoholic, to delirium tremens. Mineral homeostasis is based on dietary intake, intestinal absorption, and renal regulation $[92,93]$ however it may not be the consumption of ethyl alcohol which is significant but instead the acidity of the alcohol (typically $\mathrm{pH}: 3.5-4.5$ ) and of its metabolites. This is confirmed by considering the effect which strongly acidic soft drinks have on the body's function. The consumption of alcoholic beverages lead to progressive devitamination [94-97] i.e. it reduces the levels of vitamin cofactors which are essential for many enzymatic reactions. In addition, platelet stickiness, a classic indicator of sugar chemistries and glycation, is a common feature of the dehydration which follows the consumption of alcohol [98]. It is an indicator of platelet aggregation [99,100] which can potentially lead to the onset of cardiovascular complications.

The $\mathrm{pH}$ of diluted phosphoric acid which gives cola drinks their acidity and tang has a $\mathrm{pH}$ of typically $2.5-4.5$. The $\mathrm{pH}$ of regular and diet pops ranges from typically 2.5-3.5 whilst branded colas have a $\mathrm{pH}$ of typically 3.5 , and diet versions a $\mathrm{pH}$ of typically 4.5. Demineralization, or loss of tooth material, begins at a $\mathrm{pH}$ of circa 5.5 . Healthy people have body fluids that are slightly alkaline, in the range 7.1-7.5 $\mathrm{pH}$, whilst the general population have a $\mathrm{pH}$ of 4.5-7.5. All aspects of our function i.e. our behaviour, exercise, drink (fruit juices) and food (proteins, grains and fatty acids), creates some degree of acidity with which the body's natural buffering mechanisms are designed to cope; however acidified soft drinks and colas in particular provide an estimated 1,000-10,000 more times acidity than that experienced in normal lifestyles. Acidified soft drinks such as colas have been statistically linked to the occurrence of strokes and heart attacks [101], osteoporosis [23], gout [102], complications in pregnancy [103], paralysis [104], bone fractures [105] and an increased risk of developing cancers [106]. This is consistent with the consumption of acidity through beer and alcoholic beverages which significantly enhance the risk and occurrence of cancer(s) $[107,108,97]$.

Acute and Chronic acidosis are linked to lowered levels of potassium, bicarbonate, phosphate, and calcium [109-111]. By contrast alkaline diets [112-115] are associated with improved health and lessened levels of morbidity and mortality.

\section{PH INFLUENCES THE STABILITY OF OTHER PHYSIOLOGICAL SYSTEMS}

\section{1. pH Influences the Levels of Minerals and the Regulation of Blood Glucose}

The solubility, redox state and bioavailability of minerals is $\mathrm{pH}$ dependent. A lower $\mathrm{pH}$ influences protein conformation. Accordingly the prevailing level of acidity $(\mathrm{pH})$ dramatically influences the availability of Zinc and its ability to complex with proteins. Increasing levels of acidity and/or the nature of the mineral salts have a profound effect upon the solubility of zinc e.g.
Salt

Zinc Carbonate

Zinc Sulphate

Zinc Chloride
Solubility

0.21 gms per litre

580 gms per litre

4320 gms per litre 
Changes of acidity leads to the preferential absorption of some minerals and elimination of others. Increased acidity decreases the levels of zinc, magnesium and potassium. This leads to the preferential absorption or retention of neurotoxins e.g. cadmium, lead and mercury; and alters the balance or relationship involving copper and zinc which is considered to be an important characteristic of homeostasis.

Elevated levels of iron, linked to increased acidity, is a common feature of liver cirrhosis, diabetes, cardiac myopathy, etc.

The availability of zinc influences key physiological systems and processes e.g. zinc is involved in the function of DNA and RNA polymerases and consequently is a critical component in the synthesis of proteins. It is a component of carbonic anhydrase, angiotensin-converting enzyme, and is essential for the synthesis of haem the primary precursor of haemoglobin, and the free radical scavenger superoxide dismutase. The enzymatic synthesis of ATP is zincdependent. Lack of zinc is implicated in apoptosis [116]. The regulation of zinc homeostasis may be essential for the body's stability [117]. Increased acidity influences the ability of zinc to complex with insulin and the consequently low levels of zinc are a feature of diabetes [118]. In vitro studies indicate that the quaternary structure of insulin under physiological conditions $(\mathrm{pH}$ 6-7) is hexameric. This quaternary structure is disrupted at low $\mathrm{pH}$ levels, where monomeric and dimeric structures are observed. The loss of quaternary structure at low $\mathrm{pH}$ is concurrent with a significant reduction in activity. Accordingly, increased acidity influences the controlled release and conformation of insulin and consequently the regulation of blood glucose.

Increased acidity increases the amounts of magnesium, zinc and other minerals, which are excreted in urine. Accordingly, increased acidity of urine is a feature of the body's failed attempts to regulate its overall $\mathrm{pH}$ and results in mineral depletion [119-121]. It is a particular feature of glucose metabolism [122,123], cardiovascular disease [124127], kidney disease [128], rheumatoid arthritis [129], osteoporosis [130] and cancers [131]. It is also a feature of many solid tumours that they are more significantly acidic than normal tissues.

Proinsulin is expressed by the INS gene [132]. $\mathrm{pH}$ influences the conversion of proinsulin to insulin $[133,134]$, insulin secretion [135], and the conversion of insulin to the zinc hexamer and its storage in the pancreas - the hexamer is a zinc-bound complex which is less active and more stable at relatively neutral $\mathrm{pH}$. This availability of the zinc hexamer serves to ensure a controlled-release supply of insulin in response to glycaemic overload. Lowered extracellular $\mathrm{pH}$ shortens the half-life of insulin as it dissociates from its receptor [136] and decreases receptor affinity. Accordingly lowered $\mathrm{pH}$ is associated with lowered availability of insulin, lowered ability to regulate blood glucose and increased autonomic instability (Fig. 3). Increased acidity influences the availability of calcium and zinc which are required by proteases as part of the process of converting proinsulin to insulin [134], increases the rate at which insulin is released, and hence increases the rate at which insulin is subsequently degraded by the liver and kidneys [137]. Insulin secretion increases and the natural oscillations which regulate pancreatic function i.e the regulation of blood glucose, become increasingly erratic.

$\mathrm{pH}$ influences the neural regulation of blood glucose [138] which stabilises autonomic influence upon the function of pancreatic beta-cells [139-141]. $\mathrm{pH}$ is a mechanism which the brain can employ to reduce metabolic rate and maintain homeostasis or allostasis [142].

Ultimately, the body uses the kidneys to lower $\mathrm{pH}$ $[92,93]$ however high urinary $\mathrm{pH}$ can lead to problems in the urinary tract e.g. (i) at $\mathrm{pH}<5.5$ uric acid may precipitate and lead to uric acid stone formation, (ii) growth of candida albicans, etc.

\subsection{Lowered pH Influences Other Physiological Systems}

In addition to its effect upon blood glucose metabolism increased levels of acidity raise blood cell content and blood viscosity. This has the effect of increasing blood pressure. It lowers metabolic rate and body temperature; influences musculoskeletal/ bone metabolism; stimulates the elimination of body fluids; suppresses sexual function and reproduction; etc.

\section{HOW DOES THE BODY REGULATE THE ACCUMULATION OF ACIDITY IN BODY TISSUES?}

The body's physiology developed in response to the need to hunt or farm, walk and run, and otherwise conduct the activities required to facilitate and maintain a safe, healthy and active life. It is designed for an active lifestyle. Physical exercise performs the function of regulating the body's function [143,144]. It influences gene expression [145]. Lack of exercise influences the body's $\mathrm{pH}$ i.e. the ratio of $\mathrm{CO} 2 / \mathrm{O} 2$ in the blood, and leads to a ladder of pathologies leading to increasing morbidity and ultimately to premature mortality. It alters the coordinated function of the digestive organs, influences the absorption of essential minerals in the intestines, and influences muscle tone and function in the vasculature in addition to the legs, arms, etc. Increased acidity and lower levels of minerals are features of Diabetes Mellitus and Cardiovascular Disease(s). In periods following regular exercise, improved lung function optimises the elimination of $\mathrm{CO} 2$, and hence the regulation of $\mathrm{pH}$, in periods of high and low metabolic requirements. This leads to improved bio-availability of minerals and improved metabolic rate. An exercise program reinvigorates the natural processes which are essential for good health. Without such a program the use of drugs or other therapeutic approaches will only be 'as-good-as-can-reasonably-be-expected' i.e. seeking to stabilise the pathology and to prevent its progression. It cannot be possible to re-establish good health in those who are diabetic, overweight, and morbidly obese

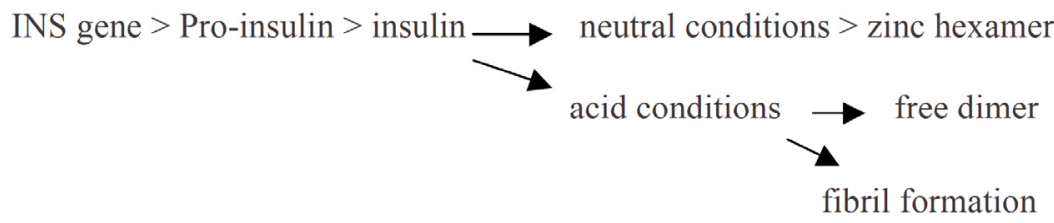

Fig. (3). The influence of $\mathrm{pH}$ upon diabetes. 
unless each has an exercise programme which can regulate extracellular $\mathrm{pH}$ and enhance the level and bio-availability of minerals required for normal metabolic function.

Measurement of $\mathrm{pH}$ e.g. in urine, is a measure of kidney function and of the kidney's ability to neutralize bile salts. Lack of exercise leads to increased acidity in urine and is an indication of the inability of the buffering systems to deal with excess acidity.

Increased levels of acidity lowers levels of magnesium and hence the function of myocytes (muscle cells) to convert glucose into energy: excess glucose being converted as triglycerides and stored by adipocytes (fat cells). In addition to its role in skeletal function exercise influences smooth muscle function which is essential for the proper function of the skeletal muscles, stomach, intestines, and all visceral organs [146]. Exercise regulates the metabolism of blood glucose [147] and improves platelet aggregation and function [148]. A wide range of genes are implicated including those which express erythropoietin, growth factors, glucose transporters, glycolytic enzymes, etc [149]. As outlined a lack of exercise may lead to the onset of diabetes and alzheimer's disease $[150,151]$.

\section{DISCUSSION}

This article highlights the complexity of the body's function and of the way in which the synchronized function of visceral organs, in particular those which are associated with the regulation of $\mathrm{pH}$, appears to be essential to the body's function and stability. It supports earlier articles by the author which illustrate how the regulation of blood glucose, blood pressure and sleep are regulated physiological systems. It is further evidence of a complex and regulated network of physiological systems and illustrates that the understanding of the nature and structure of the physiological systems are fundamental to an understanding of the down-stream mechanisms which influence and regulate gene function and cellular and molecular biology.

The brain regulates its physiological stability and hence that of the visceral organs but its function is also influenced by that of the visceral organs [152]. This is a dynamic relationship which enables the body to respond to sensory input - received through the senses, skin and also through nutrition - more commonly referred to as 'the influence of the environment' or 'phenotype'. Extremes of stress increase the body's level of acidity.

This understanding of physiological systems and their link with cognition and the autonomic nervous system serves to explain the often complex polygenic nature of disease and its many and various causes. It addresses the theoretical deficit between cognition and cellular \& molecular biology highlighted by Nobel Laureate Eric Kandel [3] and addresses the limitations of the genetic paradigm identified by Richard C. Strohman [153-155]. It defines the nature of the various environmental factors and their influence upon phenotype; and illustrates that phenotype may be more significant than genotype e.g. explaining how twins which have divergent lifestyles can have distinctly different health outcomes in later life. The genes provide a genetic predisposition however it is lifestyle-related factors which ultimately trigger the onset of pathologies.
It may illustrate that there is no viable alternative to regular exercise and a well balanced diet as a means of preventing the onset and progression of diabetes and obesity. A reasonable level of exercise is essential to maintain the muscular volume and muscle tone, volume of oxygen in blood plasma, and the regulation of $\mathrm{pH}$ which are essential for the normal biological processing of blood glucose. It indicates also that regular exercise is an essential prerequisite for the processes which involve reading, writing, the fixation and recall of memories, and mental computation.

$\mathrm{pH}$ influences the rate at which proteins are expressed and also the rate at which such expressed proteins react with their reactive substrates e.g. due to lowered levels of minerals and cofactors.

Scientific research is only able to study effects of known variables i.e. identified variables which are at a significant level. It is increasingly evident that minor changes to $\mathrm{pH}$ has a subtle influence upon our lifestyle e.g. how does minor consumption of alcoholic drinks influence our choices of partner? Could such occurrence increase our future susceptibility to conflict, divorce, etc? Whilst the behavioural symptoms and social consequences of excessive alcohol consumption and the elevated levels of systemic acidity are relatively obvious what is less obvious is how apparently minor changes of acidity influence human development and behaviour?

Gene sequencing and profiling illustrates the complexity of the body's function. It identifies the various genes which may be associated with each medical condition however there is little consideration of the genetic interactions which would be employed e.g. a medical condition can be induced by different groups of genes [156,157]. It is not the individual genes which are important but instead how the genes, and genetic conformation, influence the production of proteins and thereby influence the body's overall stability.

Each emergent pathology is the consequence of changes to the expression of proteins and also to the factors which influence protein conformation; the ability of proteins to react; the location of proteins in the cell; the prevailing $\mathrm{pH}$, levels of minerals and cofactors; the associated changes to cell morphology; and ultimately of the ability of cells to signal to other cells. Such changes are of phenotype.

There is a strong body of evidence which indicates that the regulation of $\mathrm{pH}$ is essential for normal homeostasis. Increased acidity lowers the levels of zinc which is a component of carbonic anhydrase, angiotensin-converting enzyme and is essential for the synthesis of haem, the primary precursor of haemoglobin. Accordingly increased levels of acidity will adversely influence the measurement of diabetes using $\mathrm{HbAlc}$ tests.

The greater the deviation from normal $\mathrm{pH}$ - the greater will be the rate of onset of pathologies. This highlights the influence of alcoholic drinks and acidified soft beverages which are now considered to be essential components of modern life. It illustrates the overlooked significance of acidbase balance. Apart from the obvious illustration of the effect of alcohol in a child born of a mother who consumes alcohol (foetal alcohol syndrome), perhaps of greatest concern is the legacy which we leave for future generations. The physiological changes which are the consequence of 
poor lifestyle choice and stress are likely to influence the health of many for future generations [158]. Changes to modern hyperindulgent lifestyles are essential to reduce the prevailing levels of acidity in our diet in order to prevent the onset of Diabetes Mellitus and a ladder of related pathologies.

\section{ACKNOWLEDGEMENTS}

We thank the many researchers who through their work have indirectly contributed to this article.

\section{COMPETING INTERESTS}

Graham Ewing is a Director of Montague Healthcare, a company devoted to the commercialisation of Virtual Scanning technology.

\section{REFERENCES}

[1] St Clair Gibson A, Noakes TD. Evidence for Complex System Integration and Dynamic Neural Regulation of Skeletal Muscle Recruitment during Exercise in Humans. Br J Sports Med 2004; 38: 797-806.

[2] Lambert EV, St Clair Gibson A, Noakes TD. Complex systems model of fatigue: integrative homeostatic control of peripheral physiological systems during exercise in humans. Br J Sports Med 2005; 39: 52-62.

[3] Kandel E. The new science of mind. Sci Am Mind 2006; 17: 62-7.

[4] Ewing GW, Parvez SH. The Dynamic Relationship between Cognition, the Physiological Systems, and Cellular and Molecular Biochemistry: a Systems-based Perspective on the Processes of Pathology. Act Nerv Super Rediviva 2010; 52: 29-36.

[5] Chesler M. Regulation and Modulation of $\mathrm{pH}$ in the Brain. Physiol Rev 83: 1183-221.

[6] Clark DD, Sokoloff L. Siegel GJ, et al., Eds. Basic Neurochemistry: Molecular, Cellular and Medical Aspects. Philadelphia: Lippincott 1999; pp. 637-70.

[7] Ewing GW, Parvez SH. Systemic Regulation of Metabolic Function. Biogenic Amines 2008; 22: 279-94.

[8] Ewing GW, Ewing EN. NeuroRegulation of the Physiological Systems by the Autonomic Nervous System - their relationship to Insulin Resistance and Metabolic Syndrome. Biogenic Amines 2008; 22: 208-39.

[9] Ewing GW, Parvez SH. The Multi-systemic Nature of Diabetes Mellitus: genotype or phenotype? N Am J Med Sci 2010; 2: 444-56

[10] Ewing GW. A Theoretical Framework for Photosensitivity: Evidence of Systemic Regulation. J Comp Sci Sys Biol 2: 287-97

[11] Weisz OA. Organelle acidification and disease. Traffic 4: 57-64

[12] Benink HA, McDougall MG, Klaubert DH, Los GV (2009). Direct $\mathrm{pH}$ measurements by using subcellular targeting of 5(and 6-) carboxyseminaphthorhodafluor in mammalian cells. BioTechniques 2009; 47: 769-74.

[13] Roberts SC, Gosling LM, Carter V, Petrie M. MHC-correlated odour preferences in humans and the use of oral contraceptives. Proc R Soc B Biol Sci 2008; 275: 2715-22.

[14] Simpson S, Munday P, Wittenrich M, et al. Ocean acidification erodes crucial auditory behaviour in a marine fish. Biol Lett 2011; doi: $10.1098 /$ rsbl.2011.0293

[15] Dixson DL, Munday PL, Jones GP. Ocean acidification disrupts the innate ability of fish to detect predator olfactory cues. Ecol Lett 2010; 13: 68-75.

[16] Lambers H, Piessens S, Bloem A, Pronk H, Finkel P. Natural skin surface $\mathrm{pH}$ is on average below 5 which is beneficial for its resident flora. Int J Cosmetic Sci 2006; 28: 359-70.

[17] Green J, Kleeman CR. The role of bone in the regulation of systemic acid-base balance. Contrib Nephrol 1991; 91: 61-76.

[18] Lemann J, Bushinsky DA, Hamm LL. Bone buffering of acid and base in humans. Am J Physiol Renal Physiol 2003; 285: F811-32.

[19] Bushinsky DA, Coe FL, Katzenberg C, Szidon JP, Parks JH. Arterial PCO2 in chronic metabolic acidosis. Kidney Int 1982; 22: 311-4.

[20] Wiederkehr M, Krapf R. Metabolic and endocrine effects of metabolic acidosis in humans. Swiss Med Wkly 2001; 131: 127-32.
[21] Brüngger M, Hulter HN, Krapf R. Effect of chronic metabolic acidosis on thyroid hormone homeostasis in humans. Am J Physiol 1997; 272: F648-53.

[22] Atkinson DE, Bourke E. Metabolic aspects of the regulation of systemic pH. AJP - Renal Physiol 252: F947-56.

[23] Tucker KL, Morita K, Qiao N, Hannan MT, Cupples LA, Kiel DP. Colas, but not other carbonated beverages, are associated with low bone mineral density in older women: The Framingham Osteoporosis Study. Am J Clin Nutr 2006; 84: 936-42.

[24] Dawson-Hughes B, Harris SS, Palermo NJ, Castaneda-Sceppa C, Rasmussen HM, Dallal. Treatment with Potassium Bicarbonate Lowers Calcium Excretion and Bone Resorption in Older Men and Women. J Clin Endocrinol Metab 2009; 94: 96-102.

[25] Glinsmann WH, Mertz W. Effect of trivalent chromium on glucose tolerance. Metabolism 1966; 15: 510-9.

[26] Anderson RA, Cheng N, Bryden NA, et al. Elevated intakes of supplemental chromium improve glucose and insulin variables with type 2 diabetes. Diabetes 1997; 46: 1786-91.

[27] Jovanovic-Peterson L, Gutierrez M, Peterson CM. Chromium supplementation for gestational diabetic women (GDW) improves glucose tolerance and decreases hyperinsulinemia. Diabetes 1996; 45: 337A.

[28] Lee NA, Reasner CA. Beneficial effect of chromium supplementation on serum triglyceride levels in NIDDM. Diabetes Care 1994; 17: 1449-51.

[29] Anderson RA. Chromium, Glucose Intolerance and Diabetes. J Am Coll Nut 1998; 17: 548-55.

[30] Stene LC, Hongve D, Magnus P, Rønningen KS, Joner G. Acidic Drinking Water and Risk of Childhood-Onset Type 1 Diabetes. Diabetes Care 2002; 25: 1534-8.

[31] Zakhari S. Overview: how is alcohol metabolized by the body? Alcohol Res Health 2006; 29: 245-54.

[32] Rondeau V, Commenges D, Jacqmin-Gadda H, Dartigues JF. Relationship between aluminum concentrations in drinking water and Alzheimer's disease: an 8-year follow-up study. Am J Epidemiol 2000; 152: 59-66.

[33] Jacqmin-Gadda H, Commenges D, Letenneur L, Dartigues JF. Silica and aluminum in drinking water and cognitive impairment in the elderly. Epidemiology 1996; 7: 281-5.

[34] Soni MG, White SM, Flamm WG, Burdock GA. Safety evaluation of dietary aluminum. Regul Toxicol Pharmacol 2001; 33: 66-79.

[35] De Felice FG, Vieira MNN, Bomfim TR, et al. Protection of synapses against Alzheimer's-linked toxins: Insulin signaling prevents the pathogenic binding of $A \beta$ oligomers. Proc Natl Acad Sci USA 2009; 106: 1971-6.

[36] Bushinsky DA, Smith SB, Gavrilov KL, Gavrilov LF, Li J, LeviSetti R. Chronic acidosis-induced alteration in bone bicarbonate and phosphate. Am J Physiol: Renal Physiol 2003; 285: F532-9.

[37] Arnett T. Regulation of bone cell function by acid-base balance. Proc Nutr Soc 2003; 62: 511-20.

[38] Lardner A. The effects of extracellular $\mathrm{pH}$ on immune function. $\mathbf{J}$ Leukoc Biol 2001; 69: 522-30.

[39] Blasetti A, Verrotti A, Chiarelli F, Morgese G. Immunologic changes in diabetic ketoacidosis. Minerva Pediatr 1992; 44: 181-4.

[40] Niefind K, Müller J, Riebel B, Hummel W, Schomburg D. The crystal structure of R-specific alcohol dehydrogenase from Lactobacillus brevis suggests the structural basis of its metal dependency. J Mol Biol 2003; 327: 317-28.

[41] Mukherjee R, Hollins S, Turk J. Fetal Alcohol Spectrum Disorder: An Overview. J R Soc Med 2006; 99: 298-302.

[42] McCarver DG. ADH2 and CYP2E1 genetic polymorphisms: risk factors for alcohol-related birth defects. Drug Metab Dispos 2001; 29: $562-5$.

[43] Rasmussen C. Executive functioning and working memory in Fetal Alcohol Spectrum Disorder. Alcoholism: Clin Exp Res 2005; 29: 1359-67.

[44] Mattson SN, Riley EP, Sowell ER, Jernigan TL, Sobel DF, Jones $\mathrm{KL}$. A decrease in the size of the basal ganglia in children with fetal alcohol syndrome. Alcohol Clin Exp Res 1996; 20: 1088-93.

[45] Riley EP, Matttson SN, Sowell ER, Jernigan TL, Sobel DF, Jones KL. Abnormalities of the corpus callosum in children prenatally exposed to alcohol. Alcohol Clin Exp Res 1995; 19: 1198-1202.

[46] Salamekh S, Brender JR, Hyung S-J, et al. A two-site mechanism for the Inhibition of IAPP Amyloidogenesis by Zinc. J Mol Biol 2011; 410: 294. 
[47] Whittingham JL, Scott DJ, Chance K, et al. Insulin at $\mathrm{pH} 2$ : Structural Analysis of the Conditions Promoting Insulin Fibre Formation. J Mol Biol 2002; 318: 479-90.

[48] Dabrio M, Rodríguez AR. Characterisation of zinc metallothioneins by electroanalytical techniques. Anal Chim Acta 1999; 385: 295-306.

[49] Kalinowski DS, Richardson DR. The evolution of iron chelators for the treatment of iron overload disease and cancer. Pharmacol Rev 2005; 57: 547-83.

[50] Shpyleva SI, Tryndyak VP, Kovalchuk O, et al. Role of ferritin alterations in human breast cancer cells. Breast Cancer Res Treat 2011; 126: 63-71.

[51] Sproul D, Gilbert N, Bickmore WA. The role of chromatin structure in regulating the expression of clustered genes. Nat Rev Genet 2005; 6: 775-81.

[52] Marsh JA, Dancheck B, Ragusa MJ, Allaire M, Forman-Kay JD, Peti W. Structural Diversity in Free and Bound States of Intrinsically Disordered Protein Phosphatase 1 Regulators. Structure 2010; 18: 1094-103.

[53] Guo X-W, Cole RD. Chromatin Aggregation Changes Substantially as $\mathrm{pH}$ Varies within the Physiological Range. J Biol Chem 1989; 264: 11653-7.

[54] Muller S, Bertrand E, Erard M, van Regenmortel MHV. pHinduced conformational changes in chromatin subunits measured by circular dichroism and immunochemical reactivity. Int J Biol Macromol 1985; 7: 113-9.

[55] von Herrath MG, Liu M, Haataja L, et al. Mutant INS-Gene Induced Diabetes of Youth: Proinsulin Cysteine Residues Impose Dominant-Negative Inhibition on Wild-Type Proinsulin Transport. PLoS One 2010; 5: e13333.

[56] Rowe SM, Miller S, Sorschner EJ. Cystic fibrosis. N Engl J Med 2005; 352: 1992-2001.

[57] Fischer A, Sananbenesi F, Wang X, Dobbin M, Tsai L-H. Recovery of learning and memory is associated with chromatin remodelling. Nature 2007; 447: 178-82.

[58] Rampon $\mathrm{C}$, Jiang $\mathrm{CH}$, Dong $\mathrm{H}$, et al. Effects of environmental enrichment on gene expression in the brain. Proc Natl Acad Sci USA 2000; 97: 12880-4.

[59] Kumar GS, Maiti M. DNA polymorphism under the influence of low $\mathrm{pH}$ and low temperature. J Biomol Struct Dyn 1994; 12: 183 201.

[60] Sturm J, Lang J, Zana R. Ultrasonic absorption of DNA solutions: influence of pH. Biopolymers 1971; 10: 2639-43.

[61] Inoue M, Miyoshi D, Sugimoto N. Structural switch of telomere DNA by $\mathrm{pH}$ and monovalent cation. Nucleic Acids Symp Ser (Oxf) 2005; 49: 243-4.

[62] Cavalli G. Chromosome kissing. Curr Opin Genet Dev 2007; 17: 443-50.

[63] Tannock IF, Rotin D. Acid $\mathrm{pH}$ in tumors and its potential for therapeutic exploitation. Cancer Res 1989; 49: 4373-84.

[64] Raghunand N, He X, van Sluis R, et al. Enhancement of chemotherapy by manipulation of tumour $\mathrm{pH}$. Br J Cancer 1999; 80: 1005-11.

[65] Glaser WD, Anderson KN, Anderson LE. The Mosby Medical Encyclopedia. New York: Plume 1992.

[66] McEwen BS, Stellar E. Stress and the Individual: Mechanism Leading to disease. Arch Intern Med 1993; 153: 2093-101.

[67] Elliott GR, Eisdorfer C. Stress and Human Health. New York: Springer Publishing Company 1982.

[68] Baker LH, Lieberman D, Oehlke M. Psychological distress in patients with gastroesophageal reflux disease. Am J Gastroenterol 1995; 90: 1797-803

[69] McDonald-Haile J, Bradley LA, Bailey MA, Schan CA, Richter JE. Relaxation training reduces symptom reports and acid exposure in patients with gastroesophageal reflux disease. Gastroenterology 1994; 107: 61-9.

[70] Drossman DA. Gastrointestinal illness and the biopsychosocial model. Psychosom Med 1998; 60: 258-67.

[71] Ricciardiolo FLM, Gaston B, Hunt J. Acid stress in the pathology of asthma. J Allergy Clin Immunol 2004; 113: 610-9.

[72] Harding SM. Gastroesophageal reflux, asthma, and mechanisms of interaction. Am J Med 2001; $1118 \mathrm{~A}$ : 8S-12S

[73] Ziemann A, Allen J, Dahdaleh N, et al. The amygdala is a chemosensor that detects carbon dioxide and acidosis to elicit fear behavior. Cell 2009; 139: 1012-21.
[74] Esquivel G, Schruers KR, Maddock RJ, Colasanti A, Griez EJ. Acids in the brain: a factor in panic? J Psychopharmacol 2010; 24: 639-47.

[75] Hara MR, Kovacs JJ, Whalen EJ, et al. A stress response pathway regulates DNA damage through $\beta 2$-adrenoreceptors and $\beta$-arrestin1. Nature 2011; 447(7364): 349-53.

[76] Essex MJ, Boyce WT, Hertzman C, et al. Epigenetic vestiges of early developmental adversity: Childhood stress exposure and DNA methylation in adolescence. Child Dev 2011; doi: 10.1111/j.1467-8624.2011.01641.x

[77] Epel ES, Lin J, Dhabhar FS, et al. Dynamics of telomerase activity in response to acute psychological stress. Brain Behav Immun 2010; 24: 531-9.

[78] Mao Z, Hine C, Tian X, et al. SIRT6 promotes DNA repair under stress by activating PARP1. Science 2011; 332: 1443-6.

[79] Michishita E, McCord RA, Berber E, et al. SIRT6 is a histone H3 lysine 9 deacetylase that modulates telomeric chromatin. Nature 452: 492-6.

[80] Kostoglou-Athanassiou I, Treacher DF, Wheeler MJ, Forsling ML. Bright light exposure and pituitary hormone secretion. Clin Endocrinol (Oxf) 1998; 48: 73-9.

[81] Corrigan EK. Adrenal Insufficiency (Secondary Addison's or Addison's Disease). NIH Publication No. 90-3054. Available at: http://www.pituitary.org/disorders/addisons_disease.aspx.

[82] Alexandratou E, Yova D, Handris P, Kletsas D, Loukas S. Human Fibroblasts Altercations induced by low power laser irradiation at the single cell level using confocal microscopy. Photochem Photobiol Sci 2002; 1: 547-52

[83] Opas M, Dziak E. Confocal microscopy methods and protocols. Methods Mol Biol 1998; 122: 305-13.

[84] Barrès R, Osler ME, Yan J, et al. Non-CpG Methylation of the PGC-1 $\alpha$ promoter through DNMT3B controls mitochondrial density. Cell Metab 2009; 10: 189-98.

[85] Eaton SB, Konner M. Paleolithic nutrition. A consideration of its nature and current implications. N Engl J Med 1985; 312: 283-9.

[86] Liang $\mathrm{H}$, Ward WF. PGC-1 $\alpha$ : a key regulator of energy metabolism. Adv Physiol Educ 2006; 30: 145-51.

[87] Koo S-H, Satoh H, Herzig S, et al. PGC-1 promotes insulin resistance in liver through PPAR- $\alpha$-dependent induction of TRB-3. Nat Med 2004; 10: 530-4.

[88] Kondo T, Kishi M, Fushimi T, Kaga T. Acetic acid upregulates the expression of genes for fatty acid oxidation enzymes in liver to suppress body fat accumulation. J Agric Food Chem 2009; 57: 5982-6.

[89] Abou-Donia MB, El-Masry EM, Abdel-Rahman AA, McLendon RE, Schiffman SS. Splenda alters gut microflora and increases intestinal p-glycoprotein and cytochrome p-450 in male rats. J Toxicol Environ Health A 2008; 71: 1415-29.

[90] Anderson RA, Cheng N, Bryden NA. Elevated intakes of supplemental chromium improve glucose and insulin variables in individuals with type 2 diabetes. Diabetes 1997; 46: 1786-91.

[91] Dawson-Hughes B, Harris SS, Ceglia L. Alkaline diets favour Lean Tissue mass in Older Adults. Am J Clin Nutr 2008; 87: 662-5.

[92] Maalouf NM, Cameron MA, Moe OW, Sakhaee K. Basis for Low Urine $\mathrm{pH}$ in Type 2 Diabetes. Clin J Am Soc Nephrol 2010; 5: 1277-81.

[93] Maalouf NM, Cameron MA, Moe OW, Adams-Huet B, Sakhaee K. Low urine $\mathrm{pH}$ : a novel feature of the metabolic syndrome. Clin J Am Soc Nephrol 2007; 2: 883-888.

[94] Hoyumpa AM. Mechanisms of thiamin deficiency in chronic alcoholism. Am J Clin Nutr 1980; 33: 2750-61.

[95] Pinto J, Huang YP, Rivlin RS. Mechanisms underlying the differential effects of ethanol on the bioavailability of riboflavin and flavin adenine dinucleotide. J Clin Invest 1987; 79: 1343-8.

[96] Said HM, Sharifian A, Bagherzadeh A, Mock D. Chronic Ethanol feeding and acute ethanol exposure in vitro: effect of intestinal transport of biotin. Am J Clin Nutr 1990; 52: 1083-6.

[97] Wang SD. Alcohol, vitamin A, and cancer. Alcohol 2005; 35: 2518.

[98] Bridges JM, Dalby AM, Millar JHD, Weaver JA. An Effect of dglucose on Platelet Stickiness. Lancet 1965; 285: 75-7.

[99] Shaw S, Pegrum GD, Wolff S, Ashton WL. Platelet adhesiveness in diabetes mellitus. J Clin Pathol 1967; 20: 845-7.

[100] Renaud SC, Ruf JC. Effects of alcohol on platelet functions. Clin Chim Acta 2006; 246: 77-89. 
[101] Gardener H. American Stroke Association conference, Los Angeles, February 9, 2011.

[102] Choi HK, Curhan G. Soft drinks, fructose consumption, and the risk of gout in men: prospective cohort study. Br Med J 2008; 336: 309-12.

[103] Chen L, Hu FB, Yeung E, Willett W, Zhang C. A prospective study of pre-gravid sugar-sweetened beverage consumption and the risk of gestational diabetes mellitus. Diab Care 2009; 32: 2235-41.

[104] Tsimihodimos V, Kakaidi V, Elisaf M. Cola-induced hypokalaemia: pathophysiological mechanisms and clinical implications. Int $\mathrm{J}$ Clin Pract 2009; 63: 900-2.

[105] Wyshak G, Frisch RE. Carbonated beverages, dietary calcium, the dietary calcium/phosphorus ratio, and bone fractures in girls and boys. J Adolesc Health 1994; 15: 210-5.

[106] Mueller NT, Odegaard A, Anderson K, et al. Soft Drink and Juice Consumption and Risk of Pancreatic Cancer: The Singapore Chinese Health Study. Cancer Epidemiol Biomark 2010; 19: 44755 .

[107] Benedetti A, Parent ME, Siemiatycki J. Lifetime Consumption of Alcoholic Beverages and Risk of 13 types of Cancer in Men: results from a case-controlled study in Montreaul. Cancer Detect Prev 2009; 32: 352-62.

[108] Schutze M, Boeing H, Pischon T, et al. Alcohol attributable burden of incidence of cancer in eight European countries based on results from prospective cohort study. BMJ 2011; 342: d1584.

[109] Bushinsky DA, Gavrilov K, Chabala JM, Featherstone JDB, LeviSetti R. Effect of metabolic acidosis on the potassium content of bone. J Bone Miner Res 12: 1664-71.

[110] Bushinsky DA, Smith SB, Gavrilov KL, Gavrilov LF, Li J, LeviSetti R. Acute acidosis-induced alteration in bone bicarbonate and phosphate. Am J Physiol Renal Physiol 2002; 283: F1091-7.

[111] Bushinsky DA, Smith SB, Gavrilov KL, Gavrilov LF, Li J, LeviSetti R. Chronic acidosis-induced alteration in bone bicarbonate and phosphate. Am J Physiol Renal Physiol 2003; 285: F532-9.

[112] Dawson-Hughes B, Harris SS, Ciglia L. Alkaline diets favor lean tissue mass in older adults. Am J Clin Nutr 2008; 87: 662-5.

[113] McGartland CP, Robson PJ, Murray LJ, et al. Fruit and vegetable consumption and bone mineral density: the Northern Ireland Young Hearts Project. Am J Clin Nutr 2004; 80: 1019-23.

[114] Vataparast H, Baxter-Jones A, Faulkner RA, Bailey DA, Whiting SJ. Positive effects of vegetable and fruit consumption and calcium intake on bone mineral accrual in boys during growth from childhood to adolescence: the University of Saskatchewan Pediatric Bone Mineral Accrual Study. Am J Clin Nutr 2005; 82: 700-6.

[115] Tucker KL, Hannan MT, Chen H, Cupples LA, Wilson PW, Kiel DP. Potassium, magnesium, and fruit and vegetable intakes are associated with greater bone mineral density in elderly men and women. Am J Clin Nutr 1999; 69: 727-36.

[116] Sunderman FW. The influence of zinc on apoptosis. Ann Clin Lab Sci 1995; 25: 134-42.

[117] Bozym RA, Chimienti F, Giblin LJ, et al. Free zinc ions outside a narrow concentration range are toxic to a variety of cells in vitro. Exp Biol Med (Maywood) 2010; 235: 741-50.

[118] Kinlaw WBA, Levine ASA, Morley JEA, Silvis SEA, McClain CJA. Abnormal zinc metabolism in type II diabetes mellitus. Am J Med 1983; 75: 273-7.

[119] Sjogren A, Floren CH, Nilsson A. Magnesium, Potassium and Zinc Deficiency in Subjects with Type II Diabetes Mellitus. Acta Medica Scandinavica 1988; 224: 461-6.

[120] Wältia MK, Zimmermanna MB, Spinasb GA, Hurrella RF. Low plasma magnesium in type 2 diabetes. Swiss Med Wkly 2003; 133: 289-92.

[121] Nadler JL, Buchanan T, Natarajan R, Antonipillai I, Bergman R, Rude R. Magnesium deficiency produces insulin resistance and increased thromboxane synthesis. Hypertension 1993; 21: 1024-9.

[122] McNair P, Christensen MS, Christiansen C, Madsbad S, TransbolI. Renal hypomagnesaemia in human diabetes mellitus: its relation to glucose homeostasis. Eur J Clin Invest 1982; 12: 81-5.

[123] Kao WH, Folsom AR, Nieto FJ, Mo JP, Watson RL, Brancati FL. Serum and dietary magnesium and the risk for type 2 diabetes mellitus: the Atherosclerosis Risk in Communities Study. Arch Intern Med 1999; 159: 2151-9.

[124] Mather HM, Levin GE, Nisbet JA. Hypomagnesemia and ischemic heart disease in diabetes. Diabetes Care 1982; 5: 452-3.

[125] Ma J, Folsom AR, Melnick SL, et al. Associations of serum and dietary magnesium with cardiovascular disease, hypertension, diabetes, insulin, and carotid arterial wall thickness: the ARIC study. Atherosclerosis Risk in Communities Study. J Clin Epidemiol 1995; 48: 927-40.

[126] Barbagallo M, Resnick LM. The role of glucose in diabetic hypertension: effects on intracellular cation metabolism. Am J Med Sci 1994; 307(Supp1 1): S60-5.

[127] Reffelmann T, Ittermann T, Darr M, et al. Low serum magnesium concentrations predict cardiovascular and all-cause mortality. Atherosclerosis 2011; 219: 280-4.

[128] Saldana TM, Basso O, Darden R, Sandler DP. Carbonated beverages and chronic kidney disease. Epidemiology 2007; 18: 501-6.

[129] Bobkov VA, Brylenkova TN, Kopilov EI, Mitskaia SG, Kazakova NI. Changes in the acid-base status of the synovial fluid in rheumatoid arthritis patients. Ter Arkh 1999; 71: 20-2.

[130] Qi P, LiXin G. Diabetes and osteoporosis. Zhongguo Shiyong Neike Zazhi / Chinese J Pract Int Med 2009; 29: 968-70.

[131] Costello LC, Levy BA, Desouki MM, et al. Decreased zinc and downregulation of ZIP3 zinc uptake transporter in the development of pancreatic adenocarcinoma. Cancer Biol Ther 2011; 12: 297303 .

[132] Bell GI, Pictet RL, Rutter WJ, Cordell B, Tischer E, Goodman HM Sequence of the human insulin gene. Nature 1980; 284: 26-32.

[133] Sorenson RL, Shank RD, Lindall AW. Effect of pH on conversion of proinsulin to insulin by a subcellular fraction of rat islets. Proc Soc Exp Biol Med 1972; 139: 652-5.

[134] Davidson HW, Peshavaria M, Hutton JC. Proteolytic conversion of proinsulin into insulin. Identification of a $\mathrm{Ca} 2+$-dependent acidic endopeptidase in isolated insulin-secretory granules. Biochem $\mathrm{J}$ 1987; 246: 279-86.

[135] Hyder A, Laue C, Shrezenmeir J. Effect of extracellular pH on insulin secretion and glucose metabolism in neonatal and adult rat pancreatic islets. Acta Diabetol 2001; 38: 171-8.

[136] Marshall S, Podlecki DA, Olefsky JM. Low pH Accelerates Dissociation of Receptor-Bound Insulin. Endocrinology 1983; 113 : $37-42$.

[137] Grungreiff K, Reinhold D. Liver cirrhosis and "liver" diabetes mellitus are linked by zinc deficiency. Med Hypotheses 2005; 64: 316-7.

[138] Ewing GW, Parvez SH, Grakov IG. Further Observations on Visual Perception: the influence of pathologies upon the absorption of light and emission of bioluminescence. Open Syst Biol J 2011; 4: $1-7$.

[139] Hellman B, Gylfe E, Grapengiesser E, Dansk H, Salehi A. Insulin oscillations - clinically important rhythm. Antidiabetics should increase the pulsative component of the insulin release. Lakartidningen 2007; 104: 2236-9.

[140] MacDonald PE, Rorsman P. Oscillations, intercellular coupling, and insulin secretion in pancreatic beta cells. PLoS Biol 4: e49.

[141] Taborsky GJ Jr. Islets Have a Lot of Nerve! Or Do They? Cell Metab 2011; 14: 5-6.

[142] Sudakov KV. The theory of functional systems: general postulates and principles of dynamic organization. Integr Physiol Behav Sci 1997; 32: 392-414.

[143] Kotz CM, Teske JA, Billington CJ. Neuroregulation of nonexercise activity thermogenesis and obesity resistance. Am J Physiol Regul Integr Comp 2008; 294: R699-R710.

[144] Booth FW, Shanely RA. The biochemical basis of the health effects of exercise: an integrative view. Proc Nutr Soc 2004; 63: 199-203.

[145] Booth FW, Neufer PD. Exercise Controls Gene Expression. American Scientist 2005; 93: 28-35.

[146] Little JP, Safdar A, Benton CR, Wright DC. Skeletal muscle and beyond: the role of exercise as a mediator of systemic mitochondrial biogenesis. Appl Physiol Nutr Metab 2011; 36: 598607.

[147] Booth FW, Chakravarthy M, Spangenburg EE. Exercise and gene expression: physiological regulation of the human genome through physical activity. J Physiol 2002; 543: 399-411.

[148] Broustet JP, Boisseau M, Bouloumie J, Emerian JP, Series E, Bricaud U. The effects of acute exercise and physical training on platelet function in patients with coronary artery disease. Cardiac Rehabil 1978; 9: 28-31.

[149] Semenza GL. Regulation of mammalian O2 homeostasis by hypoxia-inducible factor 1. Annu Rev Cell Dev Biol 1999; 15: 55178. 
[150] Barnes D, Yaffe K. The projected effect of risk factor reduction on Alzheimer's disease prevalence. Lancet Neurol 2011; 10: 819-28.

[151] Matsuzaki T, Sasaki K, Tanizaki Y, et al. Insulin resistance is associated with the pathology of Alzheimer disease. The Hisayama Study. Neurology 2010; 75: 764-70.

[152] Ewing GW, Ewing EN. Cognition, the Autonomic Nervous System and the Physiological Systems. J Biogenic Amines 2008; 22: 14063.

[153] Strohman RC. Linear genetics, non-linear epigenetics: Complementary approaches to understanding complex diseases. Integr Psychol Behav Sci 30: 273-82.

[154] Strohman RC. Thermodynamics - old laws in medicine and complex disease. Nat Biotechnol 2003; 21: 477-9.
[155] Nijhout HF. Metaphors and the role of genes in development. Bioessays 1990; 12: 444-6.

[156] Jaspal SK, Saleheen D, Sim X, et al. Genome-wide association study in people of South Asian ancestry identifies six novel susceptibility loci for Type 2 Diabetes. Nat Genet 2011; [Epub ahead of print].

[157] Bodhini D, Radha V, Ghosh S, Majumder P, Mohan V. Lack of association of PTPN1 gene polymorphisms with type 2 diabetes in south Indians. J Genetics 2011; 90: 323-6.

[158] Jablonka E, Raz G. Transgenerational Epigenetic Inheritance: Prevalence, Mechanisms, and Implications for the Study of Heredity and Evolution. Q Rev Biol 2009; 84: 131-76.

(c) Graham Wilfred Ewing; Licensee Bentham Open.

This is an open access article licensed under the terms of the Creative Commons Attribution Non-Commercial License (http: //creativecommons.org/licenses/by$\mathrm{nc} / 3.0 /$ ) which permits unrestricted, non-commercial use, distribution and reproduction in any medium, provided the work is properly cited. 